\title{
Interventions in Heritage Sacred Architecture after the Second Vatican Council in Croatia
}

\author{
Intervenciones en la arquitectura religiosa patrimonial en Croacia tras el Concilio Vaticano II
}

Zorana Sokol-Gojnik · University of Zagreb (Croatia), zsokol@arhitekt.hr Igor Gojnik·Independent researcher, Zagreb (Croatia), igor.gojnik@siloueta.com Marija Banić · University of Zagreb (Croatia), mbanic@arhitekt.hr

Recibido: 22/07/2019

Aceptado: 19/03/2020

(cc) BY-NC https://doi.org/10.17979/aarc.2019.6.0.6232

\begin{abstract}
In the period of the Second Vatican Council Croatia was part of Yugoslavia. A new political system promoted an atheistic worldview. The result of that process was a hostile relationship between the Church and the official government and a profound division of the Church and the society. It resulted in very rare interventions in the field of sacred architecture. Most of the interventions occurred in the adaptations of sanctuaries after the Second Vatican Council. Most of them were reflecting the lack of co-operation between experts.

The change of political system has occurred in 1990. The new democratic system brought religions freedom but the new war destabilized society again. The result is a boom in the construction of sacred buildings reflecting the crisis of that moment. In the last decade, the situation is changing due to the initiatives that bring together theologians, liturgists, architects, architectural conservators, and artists in work on sacred buildings.
\end{abstract}

\section{KEYWORDS}

Sacred Architecture, Cultural Heritage, Catholic Church, Second Vatican Council, Croatia

\section{RESUMEN}

Durante el Concilio Vaticano II, Croacia formaba parte de Yugoslavia. Un nuevo sistema político promovió una cosmovisión atea. El resultado de ese proceso fue una relación de mutua hostilidad entre la Iglesia y el gobierno oficial, y una profunda división de la Iglesia y la sociedad. Esto derivó en intervenciones extrañas en el campo de la arquitectura sagrada. La mayoría de las intervenciones ocurrieron en las adaptaciones de santuarios después del Concilio Vaticano II. Muchas de ellas reflejaban la falta de cooperación entre expertos.

El cambio del sistema político ocurrió en 1990. El nuevo sistema democrático trajo libertad a las religiones, pero la nueva guerra desestabilizó nuevamente a la sociedad. El resultado fue un boom en la construcción de edificios sagrados que refleja la crisis de ese momento. En la última década, la situación está cambiando debido a las iniciativas que reúnen a teólogos, liturgistas, arquitectos, conservadores de arquitectura y artistas que trabajan en los edificios sagrados.

\section{PALABRAS CLAVE}

Arquitectura sagrada, patrimonio cultural, Iglesia católica, Concilio Vaticano II, Croacia

Cómo CITAR: Sokol-Gojnik, Zorana, Igor Gojnik and Marija Banić. 2019. «Interventions in Heritage Sacred Architecture after the Second Vatican Council in Croatia». Actas de Arquitectura Religiosa Contemporánea 6: 114-129.

https://doi.org/10.17979/aarc.2019.6.0.6232. 


\section{CONTEXT OF THE SECOND VATICAN COUNCIL IN CROATIA}

Croatia was one of the republics of the Socialist Federal Republic of Yugoslavia in the second half of the 20th century It was the period of radical change in the social-political system. A new totalitarian socialist-communist system, which began in Yugoslavia after the Second World War in 1945, brought a new ideology whose aim was to achieve a full social equality of all members of society.

A new atheistic worldview was promoted and the result of that process was a very bad relationship between the Church and the official government and a profound division of the Church and society (Akmadža 2013). The church was excluded from public life, religion was proclaimed a private thing. Religion was abolished in schools and instead, criticism of religions was promoted. The Catholic faculty of theology was excluded from the University. The confiscation of Church property was common practice. All religious media was prohibited, it was forbidden to celebrate religious holidays. Many priests were persecuted (Mataušić 2006).

The most dramatic case was the arrest and persecution of the Archbishop of Zagreb Alojzije Stepinac who refused to separate the Catholic Church of Croatia from the Vatican. In the trial, the archbishop was convicted to 16 years of imprisonment. When the Vatican proclaimed Archbishop Stepinac the cardinal in 1952, Yugoslavia interrupted diplomatic relations with the Holy See. Cardinal Stepinac spent five years in jail and from late 1951 until his death in 1960, he was he was under house arrest in Krašić (Batelja 2017).

However, at the beginning of the 1960s, there was a crisis of the political system of Yugoslavia linked to economic reform. After years of great economic recovery between 1947 and 1953 and the large growth of industrial production, stagnation occurred and problems with the repayment of foreign loans emerged in the early 1960 s. To counteract this, an economic reform was announced in 1964 to introduce a limited market economy more similar to western capitalism. A similar process occurred in neighbor countries (Berglund et all 2010, Fiámova et all 2010, Urbán-Vukoszávlyev 2016, Urban 2019, Vukoszávlyev 2014).

In such social climate, the rigidity of the political regime eased. On June 26, 1966, the protocol which regulated relations between the Vatican and Yugoslavia was signed. The Yugoslav authorities confirmed the freedom of religion, the equality of all religious communities and the separation of the Church and the state. Freedom of religious affairs was guaranteed to the Catholic Church and the responsibility of the Vatican over the Catholic Church matters was accepted. In the following years, relations between the Church and the state slightly improved.

The construction of the first new post-war church in Zagreb in Siget, located on the main road leading from the airport to the center of the capital was allowed. In that way, the authorities wanted to show a change in the relationship with the Church (Premerl 1996; Premerl 2010; SokolGojnik 2017). In 1968, the Bible was translated into Croatian. Finally, in 1970, diplomatic relations between The Holy See and Yugoslavia were established.

A new social and political situation was much more favorable for the Church but no real freedom was achieved and it was evident in many spheres of life. For example, when designing urban plans in Zagreb, religious buildings were not included at all until the urban plan from 1986. The Church was in fear and there were very rare initiatives for the church building and reconstruction.

In the period between 1945 and 1990, only six churches were built in capital, but only one had a permit for construction. In the period after 1990, when the political system changed to the new democratic system, in just ten years, 22 churches were built. The need for religious buildings was intense due to the city expansion, but the possibility of building churches in the socialist-communist political system was very small (Sokol-Gojnik 2017) (Fig. 01). 

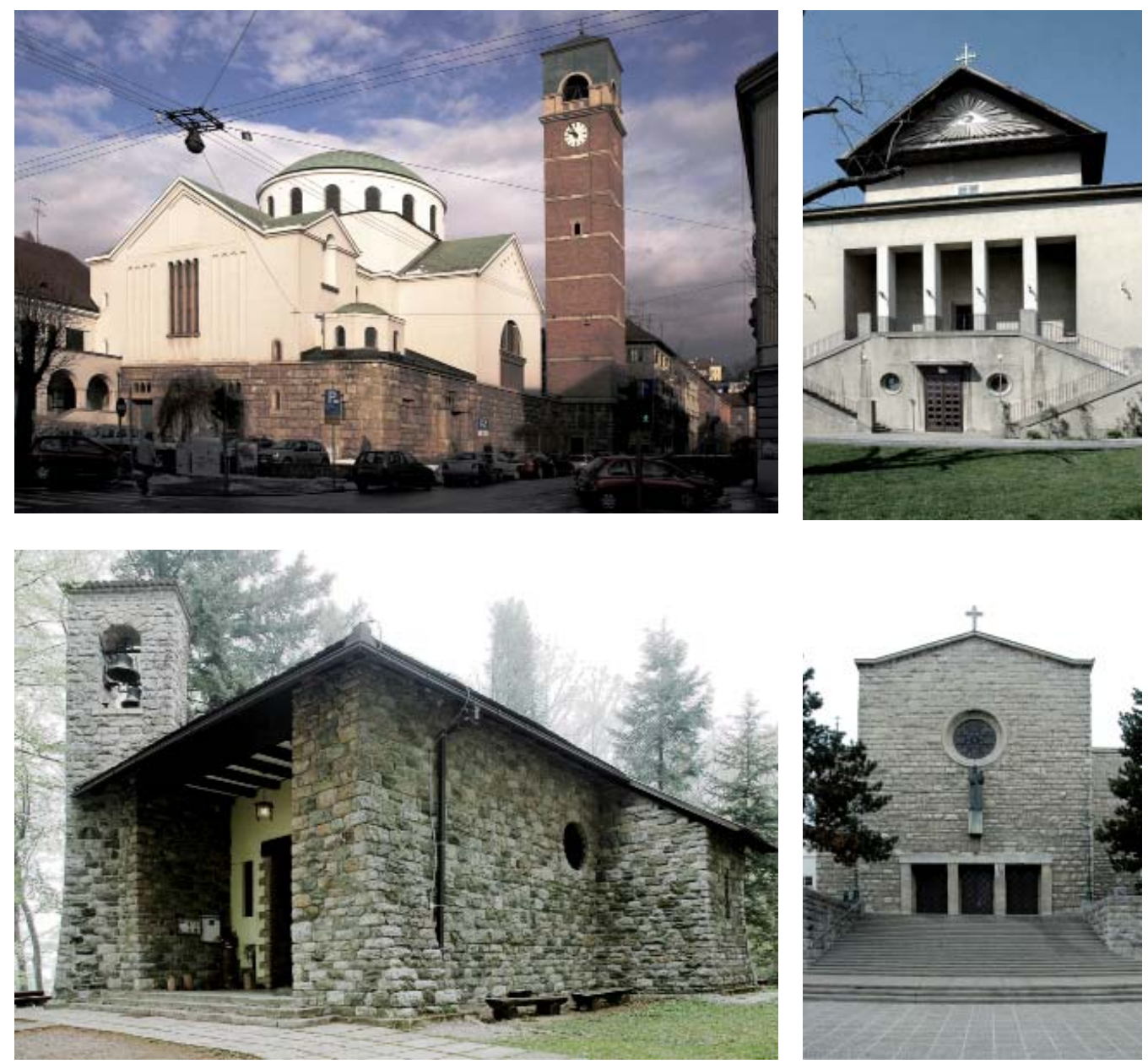

Fig. 01. Churches built in Zagreb before the First World War: Viktor Kovačić, Saint Blaise (1915); Juraj Neidhardt, Most Sacred Heart of Jesus (1931); Juraj Denzler, Saint Mary of Sljeme, Queen of Croats (1932); Juraj Denzler, St Anthony of Padua (1934); Marjan Haberle, St Marko Krizin (1940).

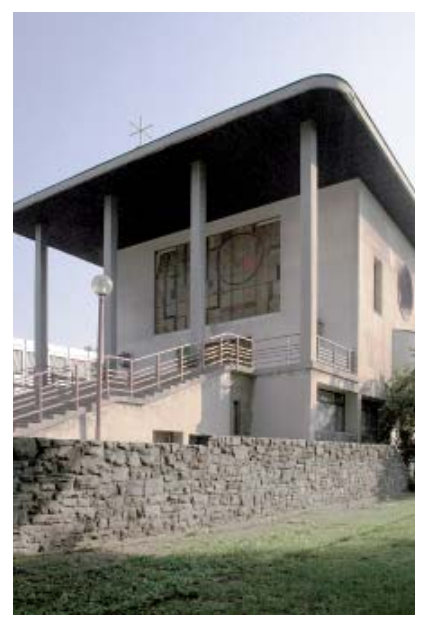




\section{INFLUENCE OF THE SECOND VATICAN COUNCIL ON THE SACRED ARCHITECTURE OF CROATIA UNTIL THE 1990S}

The first half of the 20th century of Croatian sacred architecture was characterized by the penetration of new modernist ideas based on modernist concepts such as ornament is a crime or form follows function. Although the rules of the Council of Trent gave the guidelines for the design of the sacred space, the penetration of modernist ideas resulted in new trends and new spatial concepts of sacred architecture in Croatia before the Second World War (SokolGojnik and Šćitaroci 2015).

However, the War interrupted the continuity of maturing of new modernist ideas, and the new postwar social politics system blocked the artistic maturation of these ideas in the field of sacred architecture and their permeation with the impulses of the Second Vatican Council. In the post-war period in the new social-political situation, rare artists dared to work for the Church. This resulted in a very low level of artistic achievement.

The event of the Second Vatican Council was adopted with enthusiasm in the world. The idea of the opening of the Church to the world woke up new hopes in Western society. In the Croatian context, it seemed to be a difficult task set before the Church who was feeling like a prisoner of the political system. But the launch of the paper Glas Koncila (The Voice of the Council) in 1962 was the major contribution to reach the spirit of the Council and to the implementation of its reform in Croatia (Mikić 2017). The paper transmitted and interpreted the documents that were adopted at the Council and promoted the implementation of its conclusions in the local Church.

Since the changes that the Council had determined strongly influenced the liturgy by the introduction of the national language, by turning of the altar to the people and introduction of the concelebration, the paper gave special attention to the liturgy. So Glas Koncila wrote about new solutions in church architecture in the spirit of understanding of new liturgical regulations.
Thus, the Church was prepared for the changes that should happen in liturgy and architecture through the media. However, the implementation of these changes was very slow. Changes first occurred in existing churches by reorganizing the sanctuary, removing existing altars and/or introducing new altars, while building new churches was extremely rare.

\section{INTERVENTIONS IN HERITAGE CHURCH ARCHITECTURE UNTIL 1990}

Interventions in the heritage church architecture, motivated by the changes brought by the Second Vatican Council, were mainly concerned with the redesign of the sanctuary and their adaptation to the needs of a new liturgy. However, given the social context, interventions were often fearful with an inadequate artistic level. It was the result of the lack of co-operation between experts from the field of architecture, architectural conservation and theology. In this paper, some examples of those interventions based on different approaches and levels of artistic achievement will be presented.

\section{Zagreb Cathedral}

The Zagreb Cathedral is the largest Croatian church and one of the most valuable monuments of Croatian cultural heritage. Cathedral owes its present appearance to the great historicist reconstruction after the earthquake in 1880 but its history dates back to the 11th century when the first cathedral was built after the Zagreb diocese was founded in 1094. The Cathedral got its present appearance in the period from 1880 to 1906 according to the project of viennese architect Friedrich von Schmidt. The projects were later partly modified by his disciple, architect Hermann Bollé, who left a significant work in the Croatian historicist sacred architecture (Čorak and Deanović 1988; Damjanović 2016; Kraševac 2016; Horvat 2008; Šimunić and Šimunić-Buršić 2015).

After the Second Vatican Council, a new altar versus populum was introduced into the sanctuary. In the design of the altar, an existing ceremonial silver antependium, which was made in Vienna in 1721, was used. That antependium was in use before to decorate the main altar on Christmas. The ante- 

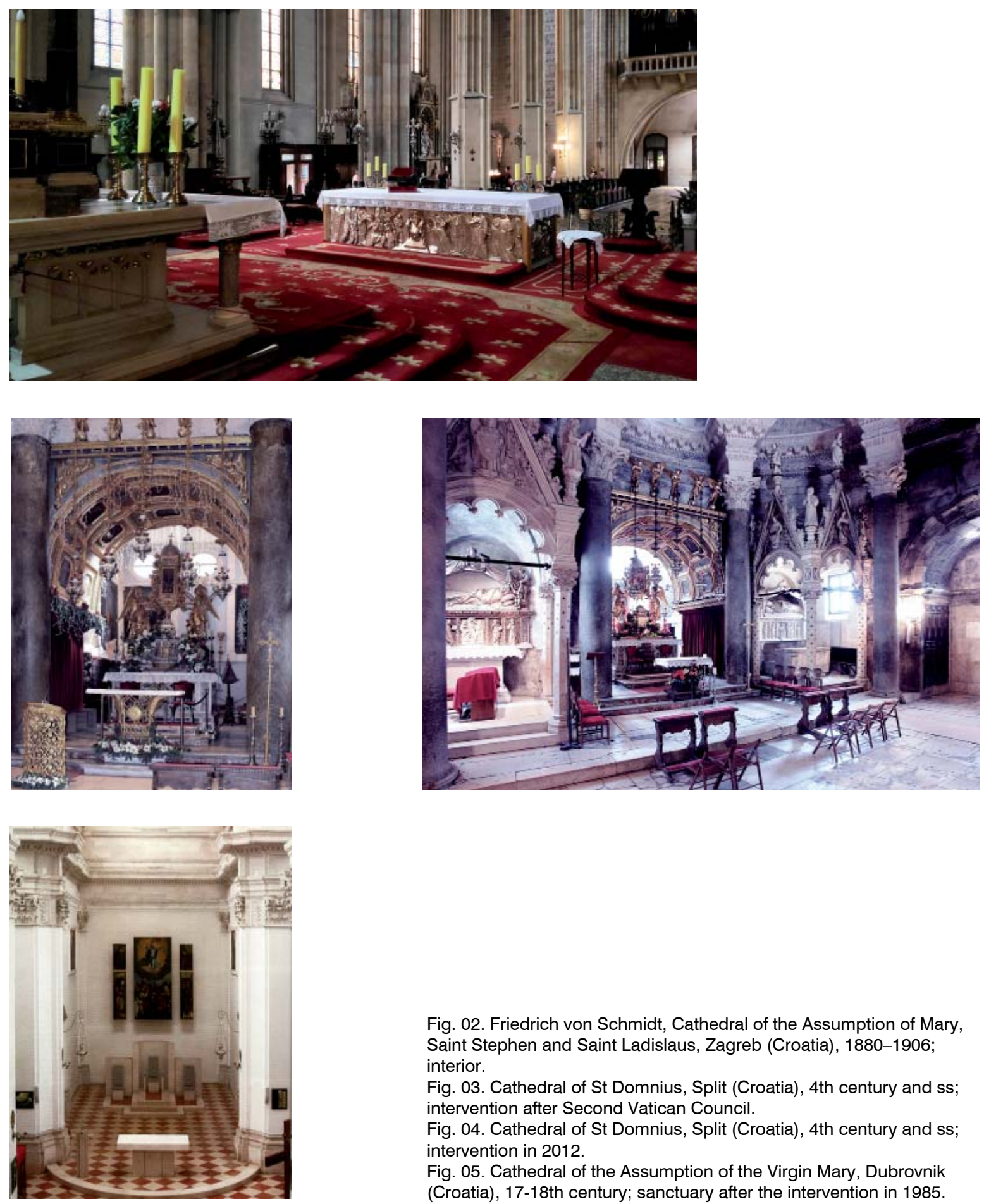

Fig. 02. Friedrich von Schmidt, Cathedral of the Assumption of Mary, Saint Stephen and Saint Ladislaus, Zagreb (Croatia), 1880-1906; interior.

Fig. 03. Cathedral of St Domnius, Split (Croatia), 4th century and ss; intervention after Second Vatican Council.

Fig. 04. Cathedral of St Domnius, Split (Croatia), 4th century and ss; intervention in 2012.

Fig. 05. Cathedral of the Assumption of the Virgin Mary, Dubrovnik (Croatia), 17-18th century; sanctuary after the intervention in 1985. 
pendium was made by jeweler Reimann from the Slovenian town Maribor in 1721. On the new altar, the front side represents The Holy Family and on the sides the Hungarian kings of Árpád dynasty: St Stjepan and St Ladislaus (the later one the founder of the Zagreb Diocese).

In 1983, the back of the altar was made according to the idea of priest A. Ivandija and realized by sculptor Stanko Jančić. In the center of the relief, there is Mother of God Queen of Croats holding Little Jesus and gathering Croatian saints, beatified, martyrs, kings and queens, monks, nuns, farmers, and intellectuals.

In the sanctuary, the sarcophagus of beatified Alojzije Stepinac made of silver in combination with other metals was also introduced. The sarcophagus was designed by the sculptor Hrvoje Ljubić. On the silver panels, the events from Stepinac life were presented. Below the sarcophagus, there are tombs of the Zagreb bishops and archbishops.

Contemporary intervention is well-integrated in the historicist context of the Zagreb cathedral and is well accepted by experts and believers (Fig. 02).

\section{Split Cathedral}

The Cathedral in Split was originally an ancient mausoleum of Emperor Diocletian raised within his palace. But in the 7th century, after the barbarian people had broken into the Roman Empire, the citizens from the nearby Roman Salona (today Solin) run away and settled in the Emperor's Palace in Split. The Emperor's mausoleum was converted into a Christian church. The palace became the basis of today's city of Split and the emperor's mausoleum became the oldest cathedral in the world.

The cathedral, which was architecturally preserved in its original form, had a baroque extension of the choir space which diminished the integral antique spatial idea. In the baroque period the cathedral also got the main altar above which two angels are holding the throne for the Sacred Sacrament with the image of the Virgin on the front side (Bužančić 2011; Duplančić 2016; Prijatelj-Pavičić and Čoralić 2002). The baroque altar was made of marble. Above the altar, there is a wooden cassette ceiling with Eucharistic themes (Matulić-Bilač 2016). The cathedral is rich in layers of sculptural and painter's interventions of different styles.

After the Second Vatican Council, a new altar versus populum was introduced in the sanctuary. That new altar did not have any artistic value. It was made as a temporary solution because of the fear of intervention in a complex historical space. The initiative to make a new solution occurred in 2012 when a new main altar and ambo were set up as the artistic work of Sculptor Frane Šitum. The altar and ambo were made of metal in a poriferous organic structure and again, they were not considered as a permanent solution and it caused divisions in the opinions of the experts.

Post Conciliar demands of the liturgy require the introduction of new elements in this complex historical space, but the professionals are indecisive about the intervention approach. This resulted in two solutions and non of them have been accepted as the final. This is an example of indecision to take a final position regarding the intervention in a complex and valuable historical UNESCO monument (Fig. 03-04).

\section{Dubrovnik Cathedral}

The Cathedral in Dubrovnik was erected between 1671 and 1713 on the site of a demolished medieval cathedral as a three-nave basilica with a dome above the center of the cross plan. The cathedral was designed in Rome according to the idea of a Dubrovnik commissioner, the famous abbot of Stjepan Gradić. The Cathedral is a unique monument showing the transfer of Roman and Sicilian Baroque in Croatia. In its equipment, there are many valuable works of domestic artist but also the artists from Naples, Genoa, Rome, Venice and Carrara, who enriched artistic production of late baroque Dubrovnik (Horvat-Levaj 2014).

In the eighties of the 20th century, the cathedral was thoroughly restored and modernized according to the changes in the liturgy given by the Second Vatican Council. A modern post-conciliar intervention started in 1985 according to the project of Ivan Prtenjak, who made several proposals for the intervention. Architect Prtenjak found the main 


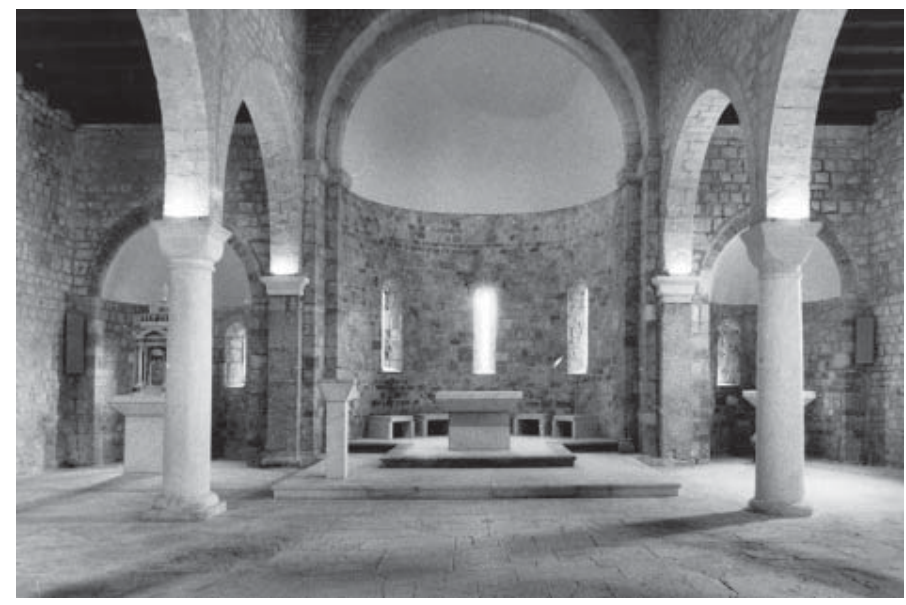

Fig. 06. St Quirinus, Krk (Croatia), 12th century; intervention in 1985.

Fig. 07. Cathedral of St Stephen I, Hvar (Croatia), 14-17th centuries; new doors, 1987-90

Fig. 08. Cathedral of St Stephen I, Hvar (Croatia), 14-17th centuries; new altar, 1990-93
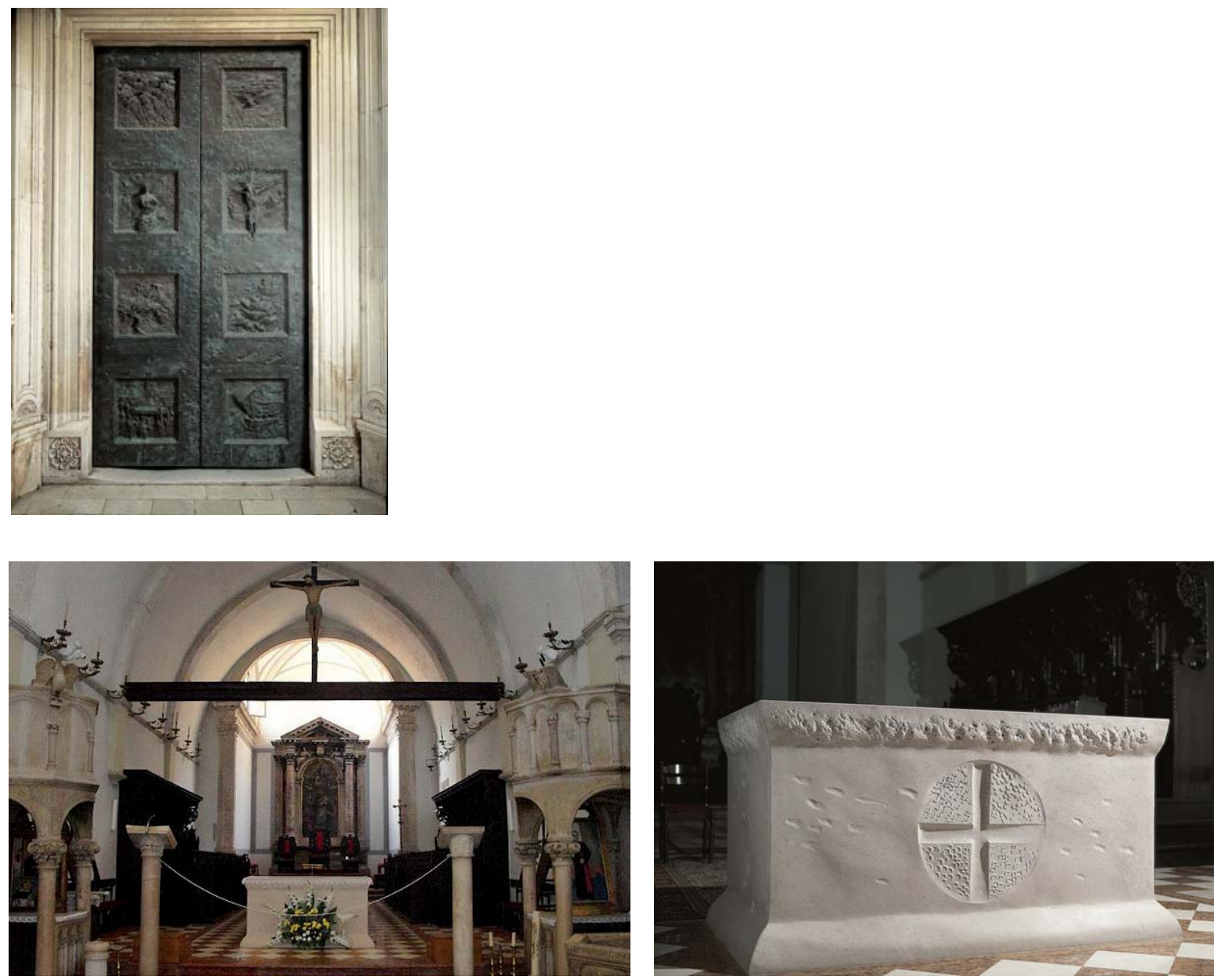
baroque altar and the choir benches already removed due to the renovation of the cathedral. His proposal included a partial restoration of the previous inventory with the addition of new elements. The architect had the intention of restoring an old altar because of its monumental value although it was not in use anymore. But the commissioner did not agree with this approach. Therefore, the architect proposed a solution that introduces a new altar versus populum and ambo with a simple modern design. The design was following the morphology of the apse of the former Romanesque cathedral (Prtenjak 1989). Tizian's polyptych is liberated from a marble neo-Renaissance retable and it is set free on the apse's wall.

This solution has led to the great controversy by the experts who declared it a sterilizing, purifying and exaggerated architectural solution that does not respect the baroque context of space and introduces a new layer too aggressively (Ivanović 2014) (Fig. 05).

Therefore, a roundable with experts from various fields was organized in 2012. The roundtable concluded the architectural solution of architect Prtenjak had depleted the space and did not reflect the historical richness of layers created over the centuries accumulated in it, creating a unity. Thereby, it diminishes the aesthetic dignity of the UNESCO protected monument. The Roundtable proposed the development of a new solution including the restoration of the Baroque altar and neo-renaissance retable. It was proposed to establish the Commission of a team of art historians, conservators, restaurateurs, archeologists, theologians, liturgists, architects who should provide guidelines for a new solution in this important UNESCO monument.

This example demonstrates the complexity of interventions in historical heritage architecture and the necessity of serious reflection and involvement of different professions in this process. The approach of this intervention was too bold and consequently recognized as inadequate.

\section{INTERVENTIONS IN CROATIAN CHURCH ARCHITECTURE AFTER 1990}

In 1990, the change from the socialist-communist to the democratic political system in Croatia occurred. When Yugoslavia fell apart, the Republic of Croatia became an independent state. This great political change has also changed the social context and attitude toward religion. The Democratic Constitution guaranteed a full freedom of religion.

Therefore, the circumstances changed and the field of freedom, even in the planning of new sacred architecture, was opened. However, a new war that happened in Croatia in 1990, which lasted for almost a decade, brought a new fear and suppressed a creative force and élan of a nation in the economic and cultural sense.

On territories not affected by the war a boom of constructions of sacred buildings was perceptible. For example, in Zagreb, in just 10 years, 22 churches were built. However, the creative crisis caused by war, lack of financial resources, the lack of co-operation between the theological and architectural profession, poorly prepared architectural programs, the lack of formation of architect during their education in sacred themes etc., resulted in a large number of realized buildings with a very low architectural and liturgical quality. By the end of the war, a large number of buildings has been built or renewed which witnesses the timidity of that historic moment.

On the other hand, a renewal spirit of the Second Vatican Council did not standardize the rules for building sacred architecture. The Second Vatican Council encouraged the renewal and began a process that requires time, reflection and openness to seeking a new authentic language of the Church.

In 2013, an increasing interest in sacred architecture was induced the Sacred Architecture course at the Faculty of Architecture in Zagreb, the establishment of cooperation with the Faculty of Theology and more common cooperation between liturgists and architects in developing sacred projects.

I will present examples of several interventions in architectural heritage realized from the turn of the 1990 s to the present days.

\section{Church of St Quirinus, Krk}

Two-storey Romanesque basilica of St Quirinus from the end of the 12th century is among the most important Romanesque buildings in Krk connected 

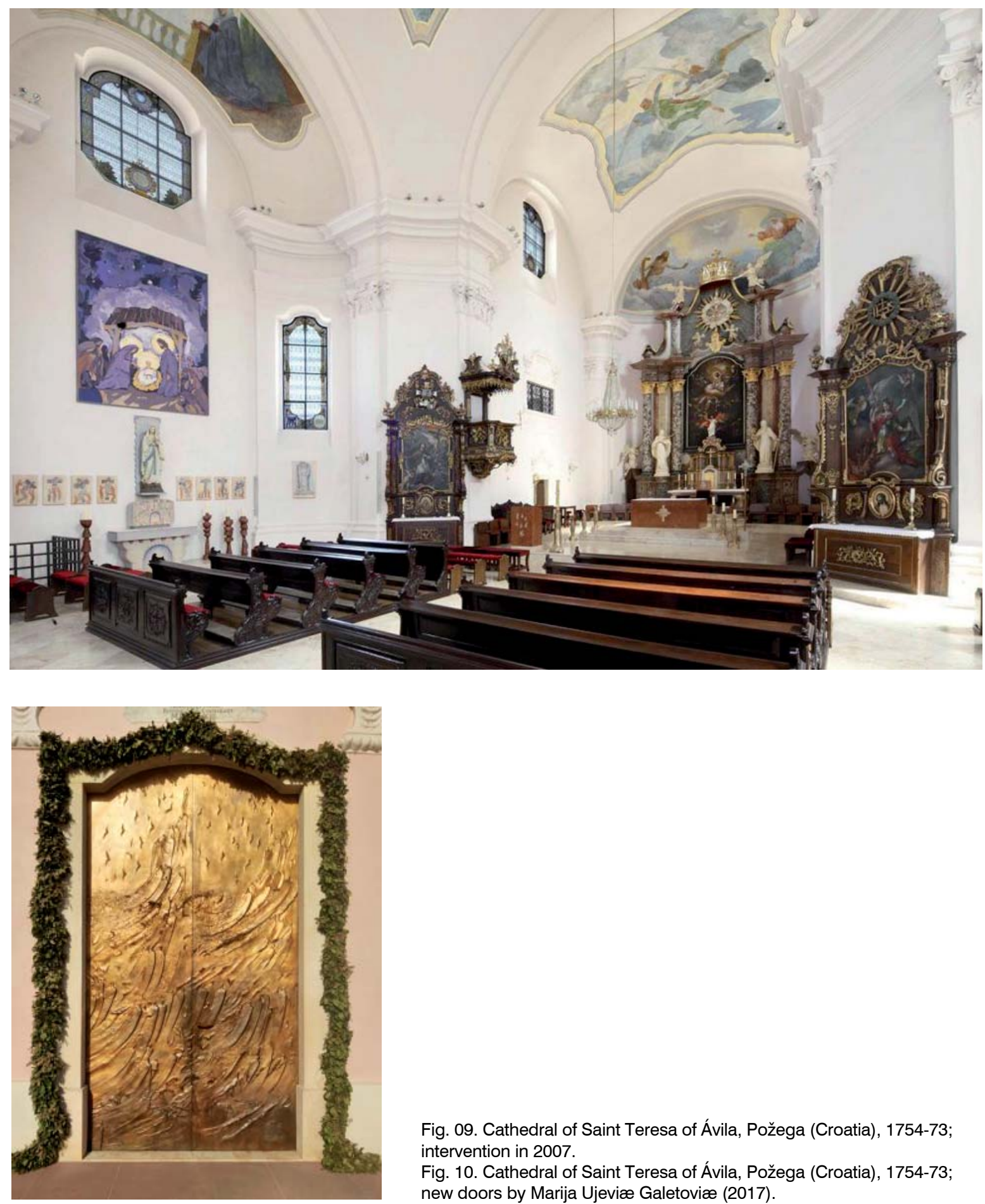

Fig. 09. Cathedral of Saint Teresa of Ávila, Požega (Croatia), 1754-73; intervention in 2007.

Fig. 10. Cathedral of Saint Teresa of Ávila, Požega (Croatia), 1754-73; new doors by Marija Ujeviæ Galetoviæ (2017). 
to the Cathedral. The upper church is dedicated to St Quirinus, the patron of the town of Krk, and the lower church is dedicated to St Margaret of Antioch. By its original function, the church of St Quirinus was the palatine chapel of the Bishop of Krk (Jurković 1992). At the beginning, the church of St Quirinus and the Cathedral were not connected. It is assumed that they were connected in 1290 when Bishop Lambert worked on the extension of the cathedral. Today the church of St Quirinus is connected with the Cathedral with large arcade.

The lower church has two, while the upper one has three naves ending with semicircular apses. The church has almost a square ground plan. During the history, both churches were in function, but in the 19th century, the church of St Quirinus became a depository. It was renewed in 1961 and in 1964, architect Tomislav Premerl made an intervention according to new liturgical needs.

The liturgical space before the intervention was organized so that the sanctuary was located in the nave. In the sanctuary, there was an altar with a tabernacle. Respecting the spirit of the Romanesque space, architect Tomislav Premerl adjusted the liturgical space to new liturgical requirements expanded the sanctuary in the side aisles. The old altar with the tabernacle was removed from the space, and the new postconciliar altar and ambo were introduced, in the connection with the cathedra long the apse wall. The baroque tabernacle was displaced in the flat apse at the end of the left aisle and in the right aisle, the architect created a place for the baroque sculpture of St Quirinus The author built a new architectural layer in subtle forms, using the material and the colors of the space before the intervention, giving the new layer of understanding based on liturgical dynamics (Fig. 06).

\section{Hvar Cathedral}

The cathedral on the island of Hvar is the monument whose history dates back to the 12th century. According to the research in the first half of the 15th century, a Gothic-Renaissance nave with lateral chapels separated by columns was added to the onenave Gothic. In the 17th century, it was replaced by the three-nave church. In the last decades of the 17th century, there was a baroque renovation of the church (Marković 2008; Pelc 2007; Fisković 1976). The construction of the facade began in the first half of the 16th century and was completed during the second half of the 18th century (Ivančević 1998). This Renaissance baroque complex with Gothic elements has a deep apse in which sanctuary was located and separated from the nave by an rood-screen.

At the end of the 1980s, Croatian Sculptor Kuzma Kovačić was called to create a new altar and new doors to this valuable monument of architectural heritage. The artist's approach consisted in an attempt to reconcile the tradition and the new, a contemporary layer. The art and architecture critics found the interventions of the doors «plastic, artistic contribution to the facade of the cathedral, but also the expression of faith» (Kovačić 1996, 148). Guided by the words that I am the door, the author divided the panel into eight new fields in which he materialized contemporary relief modeled with a soft modulation. These relief carry the themes of the history of Redemption and Salvation (Fig. 07).

The same artist made a new postconciliar altar in the church. The altar was carved out of a stone by interpreting the theme of the «capstone» (Psalm $118,22)$. The artist used the theme of sarcophagus. In the front panel, there is a symbol of the cross in the circle that is taken from the ancient altar, preserving the continuity of the heritage. There are patterns of shells and fishes appearing on the surface that link our time with the origins of Christianity. The front surface is radiant, wavy as the sea where the circle spreads waves all over the world (Kovačić 1996) (Fig. 08).

\section{Požega Cathedral}

The Požega cathedral was built as the church of St Theresa in 1759 (Horvat-Levaj 2004; Horvat-Levaj 2010). The church was built in baroque style with a frontal bell tower. The interior space is baroque with lateral chapels and sanctuary whose spaces flow from one to another building the concept of the synthesis of the longitudinal and central plans. The church was restored in the 19th century when the interior was 


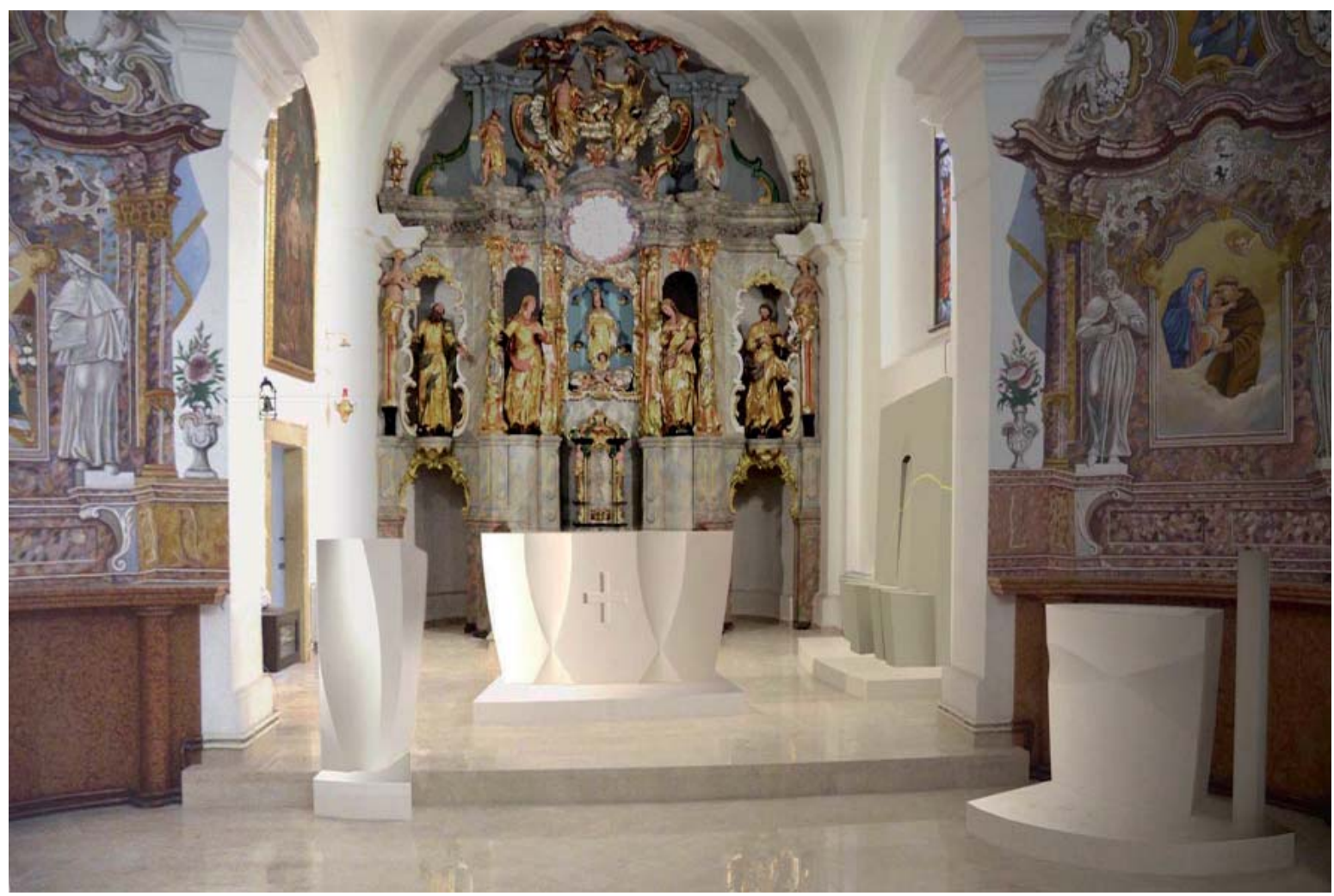

Fig. 11. Assumption of the Blessed Virgin Mary, Zagreb (Croatia), 1756; new intervention by Siloueta architecture (2015).

Fig. 12. Assumption of the Blessed Virgin Mary, Zagreb (Croatia), 1756; new intervention by Siloueta architecture (2015).

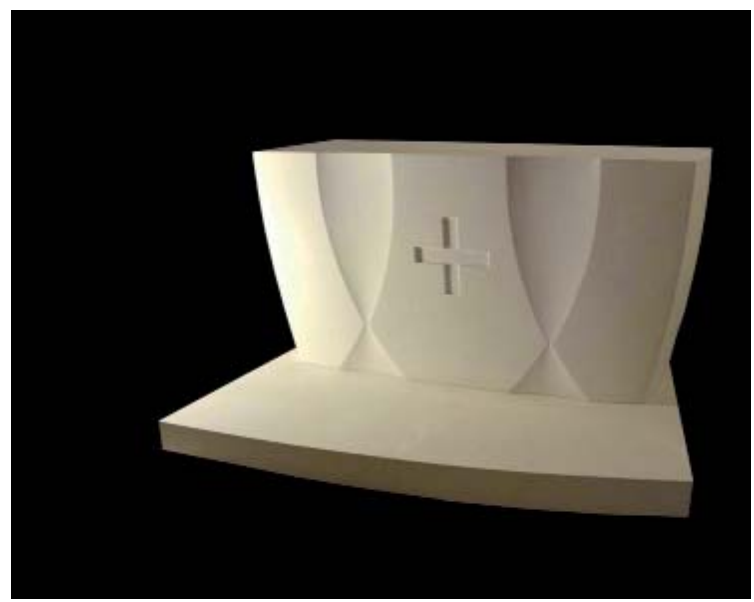


painted by famous Croatian painters Mato Celestin Medović and Oton Iveković. At that time, the church had a ceramic floor, new equipment, and side altars. The church was damaged in the 20th century but the restoration began due to its social-political circumstances in 1994.

In 1997, the church gained the status of a cathedral. In 2007, the adaptation was carried out in the context of new demands. The approach of the introduction of new elements, according to the requirements of the Second Vatican Council, was pretty heterogeneous. In the sanctuary, a new altar, ambo, candlesticks and processional crosses were introduced. The new cathedra took place in front of the ancient altar with the tabernacle. A new tabernacle, the work of Sculptor Šime Vulas, was introduced in the lateral chapel. The colorful paintings of artist Đuro Seder were placed in the lateral chapels (Fig. 09).

After receiving the cathedral status in 2017, new gates were created in the church, the work of sculptor Marija Ujević Galetović. The critic considered them as an extremely valuable artistic intervention in the baroque context of church architecture. The gates are large in size but very soft in perception because they are modulated in low relief. They bring along the spirit of Baroque architecture but also the sublimity of its function. The sculptor calls them the «Doors of Heaven» built by a multitude of figures representing souls, trees, waves and birds. On the picture the waves first carry a man, then the wind carries the soul to the sky where the birds are waiting for them and carry them in the universe, the cosmos. Contrary to the tradition of gates divided into panels, the artist realized the door as one surface bringing the novelty in the artistic approach (Fig. 10).

At the end, I would like to share with you our own experience of interventions in the cultural heritage with two projects of our office Siloueta in collaboration with liturgists.

\section{Church of the Assumption of the Blessed Virgin Mary, Brezovica, Zagreb}

The first is an intervention made in 2015 in the baroque church of Assumption of Mary in Zagreb, in which the postconciliar intervention was found inadequate. The parish requested a new contemporary project harmonized with the baroque character of the space. The design of liturgical elements should be incorporated in its invisible baroque net. We were guided by the softness of the Baroque space where the surfaces flow from one to another. But the symbolic layer of the design was enrooted in the mysteries of Christianity that we wanted to materialize in the architectural form. Thus, the altar carries the theme of Christ's multiplication of bread and fish, the theme related to the Eucharist given in simply modulated silhouette of fishes forming the altar antependium. The form of the baptistery is inspired by the symbol of the Holy Spirit which was often interpreted as the motif of the dove in the history of Christianity. The dove is inscribed in the form of the baptistery.

The intervention introduces a new symbolic layer to the baroque space, which communicates with older one and gives it an additional value that is voluble to the contemporary believer (Fig. 11-12).

\section{Church of St George, Zagreb}

Another example is the intervention in a small baroque chapel of St George in Zagreb. The task was extremely difficult because we had to introduce a new postconciliar altar in a very small space keeping a highly valuable existing golden-colored retable with the image of St George. Our approach was similar to the previous project. In the softness of baroque space, we entered with a soft form of new elements that are in harmony with the character of space. But the new form needed to create an iconographic entity with the old layer. The existing retable has iconography of the burning bush, the bush that burns and does not burn. In the existing retable, we found two angels: one carries the cross - the symbol of faith, and the other carries an anchor - a symbol of hope.

We realized that the trinity of symbols faith-hopelove is lacking love. Thus, the new altar in the composition with the Tabernacle accepted the symbol of love only with a stylized form of the heart filled with red flame lines, which unite the theme of the burning bush of an old retable to a new altar and tabernacle. The contour of the heart links the new altar and the new tabernacle. 

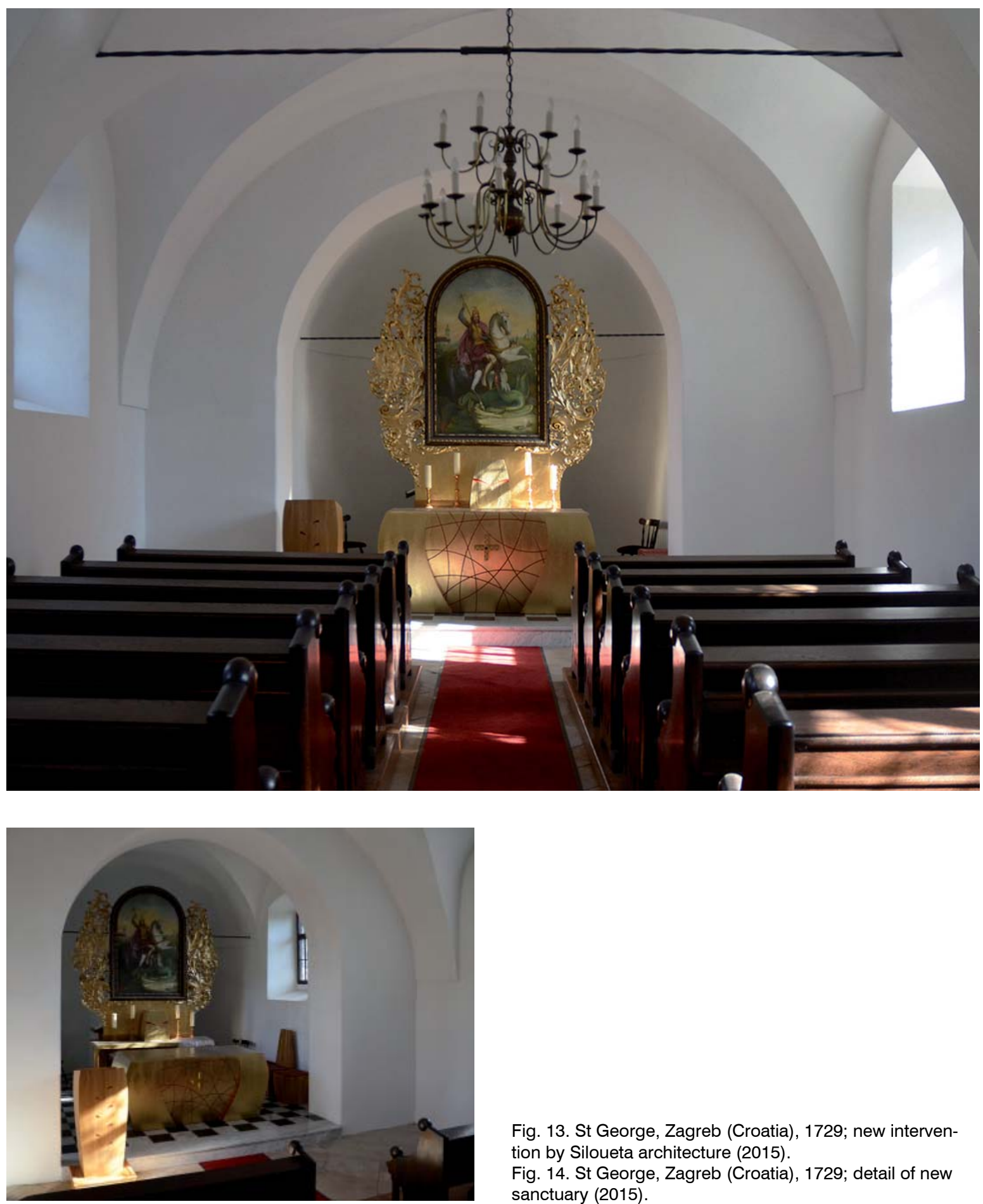

Fig. 13. St George, Zagreb (Croatia), 1729; new intervention by Siloueta architecture (2015).

Fig. 14. St George, Zagreb (Croatia), 1729; detail of new sanctuary (2015). 
On the altar, the believers celebrate Christ's sacrifice of love, the love that burns and does not burn, and the Tabernacle preserves that love that becomes the source and food of the Christian life fed in the Eucharist (Fig. 13-14).

\section{CONCLUSION}

In the first decades of the 20th-century Croatian sacred architecture was affected by the spirit of new liturgical movements present in Europe and by the spirit of modern architecture. In that time, architects were reflecting the instructions for the design of churches founded by the Council of Trent and they tried to express the centuries existing rules in a modern design. The result of this period was a very valuable church architecture most built from 1930 to 1940 .

However, the Second World War and the socio-political situation which followed the war interrupted the natural development of thoughts on sacred architecture. In the time unfavorable to religion, engaged artists were very rare. Church avoided doing architectural interventions in heritage as well as new buildings. In this context, the event of the Second Vatican Council was an incentive for new viewpoints but also put forward a new difficult task for architects.

In the 1960s, the social-political situation improved and so did the interventions in sacred architecture. But the fear and the lack of cooperation between the architects and theologians often resulted in bad interventions or temporary solutions left as a task for the future.

Croatia entered unprepared in a new democratic political system in the 1990s and war circumstances averted the possibility of serious reflection again. In the fast compensation of almost half a century of prohibition of constructing sacred buildings of sacred buildings, the mass construction of churches of low-artistic value occurred. Thus, at the turn of the 21 st century, Croatia was characterized by the crisis of disorientation in the design of sacred spaces.

But in the last decade, the problems have been more distinguished (Sokol-Gojnik and Gojnik 2019). Many initiatives are attempting to bring together theologians, liturgists, architects and artists in making comprehensive programs for sacred buildings, which can lead to a better understanding of the problem and precious architectural results. Sacred architecture requires a new enthusiasm as well as a renewal inspired by the Second Vatican Council, keeping the theological foundation from which it emerges, not dropping out of sight its ultimate meaning- the materialization of the pre-taste of Mystery not retaining in con-temporary but with the aspiration to con-eternity.

\section{BIBLIOGRAPHY}

Akmadža, Miroslav. 2013. Catholic Church in Communist Croatia 1945-1980. Slavonski Brod: Despot Infinitus.

Batelja, Juraj. 2017. Communist persecution and martyrdom of Blessed Alojzije Stepinac. Zagreb: Postulatura blaženoga Alojzija Stepinca.

Berglund, Bruce R and Brian Porter-Szücs. 2010. Christianity and Modernity in Eastern Europe. Budapest/New York: Central European University Press.

Bužancic, Radoslav. 2011. Split Cathedral. Zagreb: Turisticka naklada.

Corak, Željka and Ana Deanovic. 1988. Zagreb Cathedral. Zagreb: Globus/Kršcanska sadašnjost.

Damjanovic, Dragan. 2016. «Towers of Zagreb Cathedral. Symbols of Zagreb». Zagreb moj grad 59: 12-17.

Duplancic, Arsen. 2016. «Renovation of the main altar of the Split Cathedral in the 17th century». Prilozi povijesti umjetnosti u Dalmaciji 43(1): 303-334.

Erzsébet, Urbán and Vukoszávlyev, Zorán. 2016. «Resistance to oppression. Case study of the Hungarian Catholic Church Architecture 1945-1989». In 14th International DoCoMoMo Conference. Adaptive Reuse, edited by Ana Tostöes and Zara Ferreira, 576-581. Lisbon: DoCoMoMo International.

Erzsébet, Urbán. 2019. «Preservation of sacral heritage by learning from the paSt Church building reconstructions in Hungary in the 1960s and 1970s»». In Professionalism in the Built Heritage 
Sector. Reflections on Cultural Heritage Theories and Practices, vol. 4, edited by Koen Van Balen and Aziliz Vandesande, 147-154. London: CRC Press/Balkema.

Fiamová, Zortavili Martina and Jakubčin, Pavol. 2009. Persecution of Churches in the Communist Countries in Central and Eastern Europe. Anthology of the international conference Bratislava September 30 - October 2, 2009. Bratislava: Ústav pamäti národa.

Fiskovic, Cvito. 1976. Hvar Cathedral. Split: Cakavski sabor.

Horvat, Zorislav. 2008. «The course of construction of Zagreb cathedral». In Božic u Ciboni, edited by Božo Rudež, 144-156. Zagreb: KK Cibona/ Zagrebacka katedrala.

Horvat-Levaj, Katarina, ed. 2014. Cathedral of Our Lady in Dubrovnik. Zagreb: Institut za povijest umjetnosti.

Horvat-Levaj, Katarina. 2004. «Cathedral of St Theresa in Požega». Radovi Instituta za povijest umjetnosti 28: 208-231.

Horvat-Levaj, Katarina. 2010. «Baroque architecture». In Croatian Art. History and Monuments, edited by Milan Pelc, 249-287. Zagreb: Institut za povijest umjetnosti/Školska knjiga.

Ivancevic, Radovan. 1998. «Proportions of the Trilobe Renaissance Facades in Croatia». Peristil 41: 59-68.

Ivanovic, Marin. 2014. «Nove smjernice za uredenje svetišta». In Cathedral of Our Lady in Dubrovnik, edited by Katarina Horvat-Levaj, 489492. Zagreb: Institut za povijest umjetnosti.

Jurkovic, Miljenko. 1992. «'Doppelkapelle’ od St Quirinus in Krk. Achbishop chapel with duble function». Prilozi povijesti umjetnosti u Dalmaciji 32(1): 223-235.

Kovacic, Kuzma. 1996. «My sculptural interventions in the renovation of the Hvar cathedral». In Bogoslužni prostor- Crkva u svjetlu teologije, arhitekture i umjetnosti (Book of conference Savjetovanje za upravitelje crkava, arhitekte i umjetnike, Split 17-18 october 1995), edited by Bernardin Škunca, 147-151. Zadar: Hrvatski institut za liturgijski pastoral.
Kraševac, Irena. 2016. «Neogothic instead of Baroque. The altars of Zagreb cathedral». Zagreb moj grad 60: 18-22.

Marković, Vladimir. 2008. «The facade of the cathedral of Hvar». In Renesansa i renesanse u umjetnosti Hrvatske (Book of conference Dani Cvite Fiskovica II), edited by Predrag Marković and Jasenka Gudelj, 269-280. Zagreb: Odsjek za povijest umjetnosti Filozofskog fakulteta Sveucilišta u Zagrebu.

Mataušic, Juraj Mirko. 2006. «Acceptance of the Second Vatican Council in Croatia». Casopis za suvremenu povijest 2(38): 499-521.

Matulic Bilac, Žana. 2016. «Glavni oltar splitske katedrale uznesenja Blažene djevice Marije - tehnološke i kronološke analize». Godišnjak Hrvatskoga restauratorskog zavoda 7: 49-84.

Mikic, Anto. 2017. «The Second Vatican Council and the postconciliar renewal in paper Glas Koncila from 1963 to $1972 »$. Obnovljeni život 4(72): 443-458.

Pelc, Milan. 2007. Renesansa. Zagreb: Naklada Ljevak.

Premerl, Tomislav. 1996. The new church architecture in Zagreb. Zagreb: Galerija Modulor.

Premerl, Tomislav. 2010. «The Sacred Architecture of the Twentieth Century in Croatia». In Hrvatska arhitektura u XX. Stoljecu (Book of conference, Zagreb, 8-10 november 2007), edited by Tomislav Premerl, 211-225. Zagreb: Matica hrvatska.

Prijatelj-Pavicic, Ivana and Lovorka Coralic. 2002. «Contibution to the Knowledge of Baroque Altars in Split Cathedral». Radovi Instituta za povijest umjetnosti 26: 69-87.

Prtenjak, Ivan. 1989. «Reconstruction of the interior of the Dubrovnik cathedral». In Obnova Dubrovnika 1979-1989, edited by Snješka Kneževic, 336-338. Zagreb: Zavod za obnovu Dubrovnika.

Šimunic, Ivana and Marina Šimunic-Buršic. 2015. «Svod sakristije zagrebacke katedrale», Prostor 2(50): 344-353.

Sokol-Gojnik, Zorana and Igor Gojnik. 2019. «Lendmark Phenomenology of Sacred Architecture as Cultural Heritage». In Cultural Urban Heritage. 
Development, Learning and Landscape Strategies, edited by Mladen Obad-Šcitaroci, Bojana B.O. Šcitaroci and Ana Mrda, 289-303. Cham: Springer. Sokol-Gojnik, Zorana and Mladen ObadŠcitaroci. 2015. «Zagreb's liturgical architecture of modernism between the two world wars». Prostor 2(50): 265-275.

Sokol-Gojnik, Zorana. 2017. «Sacred architecture of Zagreb in 20th century». Zagreb: Faculty of Architecture and UPI2M Books.

Vukoszávlyev, Zorán. 2014. «Church At The Border - Church Architecture in Hungary from the start of 20th Century: Architettura di chiese in Ungheria nel XX secolo - Chiese sul confine». In
Arte Architettura Liturgia Esperienze internazionali a confronto 6, edited by Giorgio Della Longa, Antonio Marchesi and Walter Zahner, 17-41. Venezia: AlcionEdizioni.

Vukoszávlyev, Zorán. 2015. «Perception of Latin America's church architecture in the time of II Vatican Council - Studies from East-Central Europe». In Actas de Arquitectura Religiosa Contemporánea 4: 46-53. https://doi.org/10.17979/aarc.2015.4.0.5118.

\section{SOURCE OF IMAGES}

Fig. 01-04, 06-14. Authors' archive.

Fig. 05. Horvat-Levaj 2014. 